\title{
Latviešu valodas sintaktiski marḳētā korpusa gramatikas modelis
}

\section{The grammar model of Latvian Treebank}

\section{Laura Rituma, Baiba Saulīte, Gunta Nešpore-Bērzkalne}

Latvijas Universitātes Matemātikas un informātikas institūts

Mākslīgā intelekta laboratorija

Raina bulvāris 29, Rīga, LV-1050

E-pasts:laura@ailab.lv,baiba@ailab.lv,gunta@ailab.lv

Rakstā aplūkota „Latviešu valodas sintaktiski marḳētā korpusa” izveide un attīstība, kā arī raksturots tajā izmantotais gramatikas modelis. Šis korpuss ir pirmais sintaktiski marķētais korpuss latviešu valodā, un šobrīd tā apjoms ir sasniedzis ap 13000 sintaktiski marķētu teikumu. Lai iespējami precīzi aprakstītu latviešu valodas sintaktiskās konstrukcijas, korpusa marķēšanai ir izveidots hibrīds gramatikas modelis, kas ir balstīts atkarību sintaksē un papildināts ar frāzes struktūras sintakses elementiem. Ar frāzēm tiek attēlotas analītiskas vārdu formas un sintaktiskas vienības, starp kurām nav pakārtojuma sakars - salikti izteicēji, vienlīdzīgi teikuma locekḷi, vairākvārdu nosaukumi u.c. Modeḷa pamatā ir Lisjēna Tenjēra (Lucien Tesnière) ideja par sintaktiskajām vienībām, kas sastāv no vairākiem vārdiem, bet funkcionē kā viena sintaktiskā vienība.

Korpusa veidotāju izvēlētā marķēšanas pieeja un datu transformācijas iespējas nodrošina to, ka korpuss lietotājiem ir pieejams hibrīdā gramatikas modeḷa formātā, kas ir ērtāks latviešu valodas sintakses izpētei, un universālo atkarību formātā, kas ir piemērotāks valodas tehnoloğijām.

Atslēgvārdi: latviešu valodas sintakse; sintaktiski marķēts korpuss; gramatikas modelis; atkarību sintakse; frāzes struktūras sintakse.

\section{Ievads}

Sintaktiski marķēts korpuss ir nepieciešams gan valodas tehnoloǵijās valodas automātiskās analīzes rīkos -, gan arī valodniecībā - dažādu sintaktisko konstrukciju pētīšanā, konkrētu leksēmu saistīšanās spējas analīzē u.c. Tagad arī latviešu valodai ir izveidots ap 13000 teikumu liels sintaktiski markēêts korpuss „Latviešu valodas sintaktiski marḳētais korpuss” (turpmāk tekstā - LVTB) ${ }^{1}$. Tas ir automātiski morfoloǵiski marḳēts un manuāli sintaktiski marķēts tekstu kopums,

LVTB ir izstrādāts ERAF praktiskas ievirzes pētījumu projektā „Daudzslāņu valodas resursu kopa teksta semantiskai analīzei un sintēzei latviešu valodā" (1.1.1.1/16/A/219) sinerǵijā ar ERAF pēcdoktorantūras pētniecības atbalsta projektu „No abstraktās nozīmes reprezentācijas līdz dabiskam teikumam un saistītam tekstam" (1.1.1.2/VIAA/1/16/188). 
kurā katram teikumam ir kokveida struktūra un katram teikuma elementam sintaktiskā loma. LVTB izveidē izmantots hibrīds gramatikas modelis - atkarību sintaksē balstīts gramatikas modelis, kas papildināts ar frāzes struktūras gramatikas elementiem.

LVTB tiek nodrošināts divos formātos - hibrīdā gramatikas modeḷa formātā un universālo atkarību formātā. Hibrīdā gramatikas modeḷa formātā korpuss pieejams ${ }^{2}$ LINDAT/CLARIN Valodas pētniecības infrastruktūras centra (Centre for Language Research Infrastructure in Czech Republic) izveidotajā platformā dažādu valodu sintaktiski marķētu korpusu attēlošanai. Lai pievienotos starptautiskai iniciatīvai „Universālās atkarības”’3 (Universal Dependencies) un radītu iespēju LVTB izmantot arī daudzvalodu projektos, korpusa dati automātiski tiek transformēti arī universālo atkarību formātā, kas piedāvā universālas kategorijas un vadlīnijas, lai nodrošinātu saderīgu marḳējumu līdzīgām konstrukcijām dažādās valodās (vairāk nekā 100 korpusu 70 dažādām valodām) (Nivre et al. 2016).

Lai izveidotu sintaktiski marḳētu korpusu, vispirms bija jāizstrādā vai jāpielāgo gramatikas modelis, kā arī jāizvēlas marḳēšanas rīks. Pēc tam, marḳējot datus, tika attīstītas arī korpusa automātiskās pirmapstrādes iespējas, lai marķēšanas procesu varētu paātrināt. Š $\overline{1}$ raksta 2. nodaḷā aprakstīts, kā LVTB veidojies un attīstījies laikā no 2007. gada līdz 2019. gadam un kādi teksti tajā tiek iekḷauti. 3. nodaḷā plašāk aprakstīts LVTB gramatikas modelis.

\section{Latviešu valodas sintaktiski marḳētā korpusa izveide un attīstība}

„Latviešu valodas sintaktiski marķētā korpusa” izveide sākās 2007. gadā ar Sem-Ti-Kamols gramatikas model̦a izstrādi (Bārzdiņš, Grūzītis, Nešpore, Saulīte 2007). Par piemērotāko formālo modeli latviešu valodas sintakses teorijā aprakstīto parādību attēlošanai tika atzīts atkarībās balstīts hibrīds gramatikas modelis (sk. 3. nodaļu). Jau no paša korpusa izveides sākuma tika meklēti risinājumi, lai datus kaut daḷēji varētu marķēt automātiski, tādēḷ tika izveidots arī automātisks likumos balstīts gramatikas analizators, kas piedāvāja vairākus morfoloǵiskās (Paikens 2007) un sintaktiskās analīzes variantus un spēja diezgan precīzi izanalizēt atsevišķas vārdkopas. Tomēr cilvēkam šajā rīkā bija jāizvēlas, kuru morfolog̣iskās analīzes variantu katrai vārdformai apstiprināt, un analizators sintaktiski pareizi marķēja tikai nelielus teikuma fragmentus, pārējo teikuma struktūru vajadzēja marķēt manuāli, un tas padarīja marķēšanas procesu lēnu. Kā galvenais sintakses marķēšanas rīks izmantots Kārḷa Universitātē izstrādātais sintakses koku redaktors TrEd (Hajič, Hladká, Pajas 2001), ar kuru saderīgais datu formāts PML tika pielāgots latviešu valodas vajadzībām (Pretkalniņa, Nešpore, Levāne-Petrova, Saulīte 2011a).

Korpusa mājaslapā sintakse.korpuss.lv pieejama saite uz aktuālo laidienu (šobrīd 2.5. laidiens).

3 Pieejams: http://universaldependencies.org/. 
Šādā veidā vairāku gadu garumā tika markēeti ap 1500 teikumu (manuāli marķēja viens cilvēks), paralēli attīstot gramatikas modeli (Pretkalniņa, Nešpore, Levāne-Petrova, Saulīte 2011b; Pretkalniņa, Rituma 2012), un šāds apjoms jau deva iespēju izveidot parsētāju jeb automātisku sintaktisko analizatoru, kas tiktu apmācīts uz jau marķētajiem datiem un veiktu datu statistikā balstītus minējumus. Diemžēl šādi parsētāji datorlingvistikā ir pieejami vai nu atkarību, vai arī frāzes struktūras gramatikas modeḷiem, bet ne tādam hibrīdajam gramatikas modelim, kāds tiek lietots LVTB. Tādēl dati tiek transformēti atkarību formātā, izmantojot tos, tiek apmācīts parsētājs, un parsētāja iegūtais rezultāts ir atkarību formātā. Sākotnēji tas nedeva iespēju paātrināt datu manuālo marķē̌sanu hibrīdajā gramatikas modelī, bet tajā laikā attīstījās automātiskā morfologiskā analīze - tika izveidots automātiskais tagotājs jeb morfologiskais analizators (Paikens, Rituma, Pretkalniņa 2013), tādēḷ datus varēja marḳēt ātrāk un LVTB apjoms pieauga līdz apmēram 5000 teikumu 2014. gadā.

2016. gada beigās sākās jauns posms LVTB attīstībā, kad projektā „Daudzslāṇu valodas resursu kopa teksta semantiskai analīzei un sintēzei latviešu valodā” tika strauji attīstīts izmantotais gramatikas modelis, paātrināta marķē̌sana (marḳē trīs cilvēki), izveidota likumos bāzēta datu transformācija uz universālo atkarību formātu (Pretkalnina, Rituma, Saulīte 2016), apmācīts jauns parsētājs (Znotiṇš 2016) un izveidota likumos bāzēta transformācijas sistēma atpakal uz hibrīdo gramatikas modeli (Grūzītis et al. 2018). Tas beidzot ir ḷāvis iegūt automātiski marḳētus datus hibrīdā gramatikas modeḷa formātā. Šie dati joprojām ir tikai daḹēji pareizi, bet tos manuāli labot un papildināt ir krietni vieglāk nekā iepriekš, un tas savukārt palīdz straujāk palielināt korpusa apjomu. 2019. gada nogalē LVTB apjoms ir sasniedzis ap 13000 teikumu.

Laika gaitā ir mainījušies arī LVTB iekḷaujamo tekstu atlases principi. Pirmais markēetais teksts bija 100 teikumi no Justeina Gordera grāmatas „Sofijas pasaule” (1996, no norvēǵu valodas tulkojusi Brigita Šilina), jo tieši šos teikumus tolaik marķēja daudzās valodās, lai nodrošinātu sintaktiski marķētu paralēlo tekstu korpusu. Vēlāk tika marḳēta arī latviešu oriǵinālliteratūra - dažādu autoru stāsti. Laikā, kad korpusa dati bija nepieciešami sadarbības projektā ar ziņu aǵentūru LETA, tika marķeta publicistika - ziņu raksti, arī intervijas.

2017. gadā tika formulēti daudzslāņu valodas resursu kopas izveides principi: visiem gramatiskā un semantiskā marķejuma līmeņiem tika izvēlēts viens un tas pats tekstu kopums - reprezentatīva apmēram 10000 teikumu kopa, kas atlasīta no „Līdzsvarotā mūsdienu latviešu valodas tekstu korpusa” (LVK2018; LevānePetrova 2019). Lai nodrošinātu datu kopas līdzsvarotību, šo korpusu veido no atsevišķām rindkopām (nevis pilniem tekstiem) tā, lai tajā būtu pārstāvēti 2000 LVK2018 biežāk lietotie verbi (Grūzītis et al. 2018). Īpaši izveidotā rindkopu šķirošanas un atlases rīkā tiek izvēelētas rindkopas no dažādu stilu tekstiem, ievērojot šādas proporcijas (tās tikai nedaudz atškiras no LVK2018 proporcijām) $60 \%$ periodika, $20 \%$ dailliteratūra, $7 \%$ zinātniski teksti, $6 \%$ normatīvi teksti, $5 \%$ Saeimas stenogrammas un 2\% citi teksti (Grūzītis et al. 2018). 


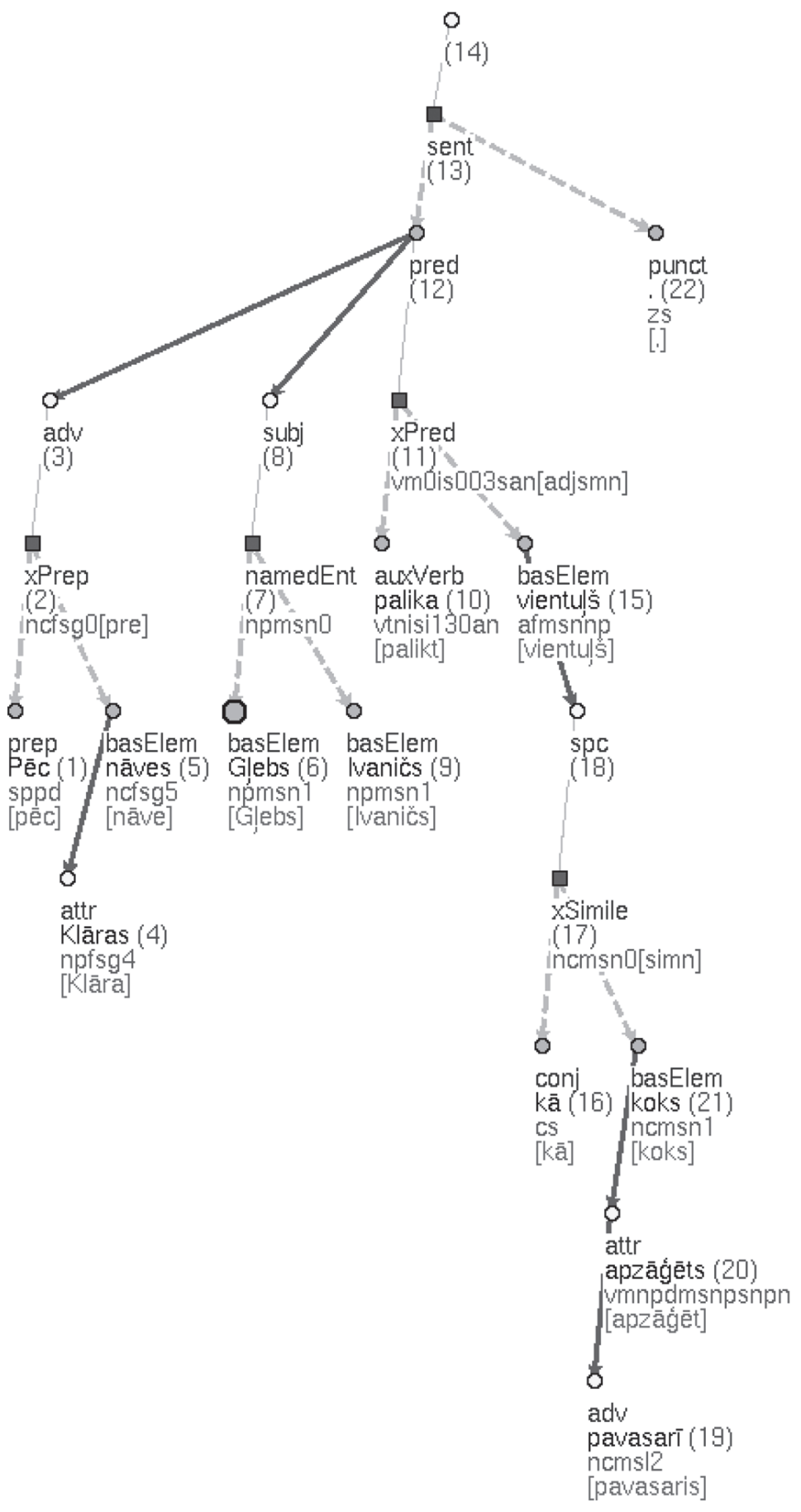

1. attēls. Teikuma Pēc Klāras nāves Gḷebs Ivaničs palika vientul̦ koks sintakses koks 


\section{3. „Latviešu valodas sintaktiski marḳētajā korpusā” izmantotais gramatikas modelis}

„Latviešu valodas sintaktiski mark̦ētajā korpusā” ir izmantots hibrīds gramatikas modelis, kas ir balstīts atkarību sintaksē un papildināts ar frāzes struktūras gramatikas elementiem. Teikuma struktūra šajā pieejā tiek attēlota kā atkarību sintakses koks, kas papildināts ar dažādām frāžu veida konstrukcijām (sk. 1. attēlu). Atkarības attēlo atsevišķus vārdus vai vairākvārdu frāzes. Frāzes tiek izmantotas, lai attēlotu vairākvārdu formas un izteicienus, t. i., sintaktiskas vienības, ko veido analītiskas formas (piem., darbības vārda saliktā laika forma), vai sintaktiskas vienības, starp kurām nav pakārtojuma sakara (piem., vienlīdzīgi teikuma locekḷi) (Pretkalniņa, Rituma, Saulīte 2018). Modelis ir balstīts uz Lisjēna Tenjēra (Lucien Tesnière 1959) ideju par sintaktiskām vienībām (franču val. nucléus), kas sastāv no vairākiem vārdiem, bet funkcionē kā viena sintaktiska vienība (sk. arī Nešpore, Saulīte, Bārzdiņš, Grūzītis 2010). Gan frāzei, gan tās sastāvdaḷām (atsevišķiem vārdiem) var būt atkarīgie komponenti.

Šāds modelis vislabāk liauj attēlot latviešu sintakses teorijā minētās analītiskās leksēmas (verba saliktie laiki, skaița vārdu savienojumi) un saliktos teikuma locekḷus (vārdkopas analogi, vārdrindas analogi, vairākvārdu nosaukumi). Modelis ir piemērots arī plašākas sintaktiskās paradigmas izpratnes atainošanai, jo struktūras shēmā ḷauj iekḷaut izteicējus ar semantisko modificētāju, piem.:

(1) Es gribu strādāt.

(2) Man laimèjās strādāt kopā ar viņu.

Tāpat šādā modelī var norādīt šḳīumu starp vārda sakaru nosacītiem teikuma paplašinātājiem un teikuma sakaru nosacītiem paplašinātājiem, radot iespēju pēdējos attēlot kā elementus, kas atkarīgi no visa teikuma vai teikuma daḷas. Modelis l̦auj šķirt teikuma locekli, kas pakārtots visiem vienlīdzīgiem teikuma locekḷiem, no teikuma locekḷa, kas pakārtots tikai vienam no vienlīdzīgiem teikuma locekliem (sk. 3. attēlu).

Hibrīdais gramatikas modelis paredz arī iespēju attēlot redukciju - ja teikumā ir izlaists kāds teikuma struktūras elements, kam pakārtoti citi teikuma locekḷi, tiek izveidota īpaša redukcijas virsotne. Reducētu virsotņu attēlošana, ja virsotnei nav teikumā realizētu pakārtotu elementu, ir paredzēta tikai tad, ja tiek atjaunoti reducēti palīgverbi (sk. auxVerb 2. attēlā), reizēm reducēti semantiskie modificētāji:

(3) Lai noskaidrotu iemeslus, [ịr] nepieciešama mediķa konsultācija.

Atjaunotajai virsotnei norāda trūkstošās vārdformas morfologiijas tagu (sk. vārdformas ir morfologisiskās pazīmes 2. attēlā), speciālā laukā var būt norādīta reducētā vārdforma, ja to var noteikt no konkrētā teikuma, bet, ja nevar, tad tikai tās morfologiskās pazīmes, kuras ir iespējams noteikt. Konkrētas vārdformas noteikšanā netiek izmantota informācija no blakus teikumiem. 


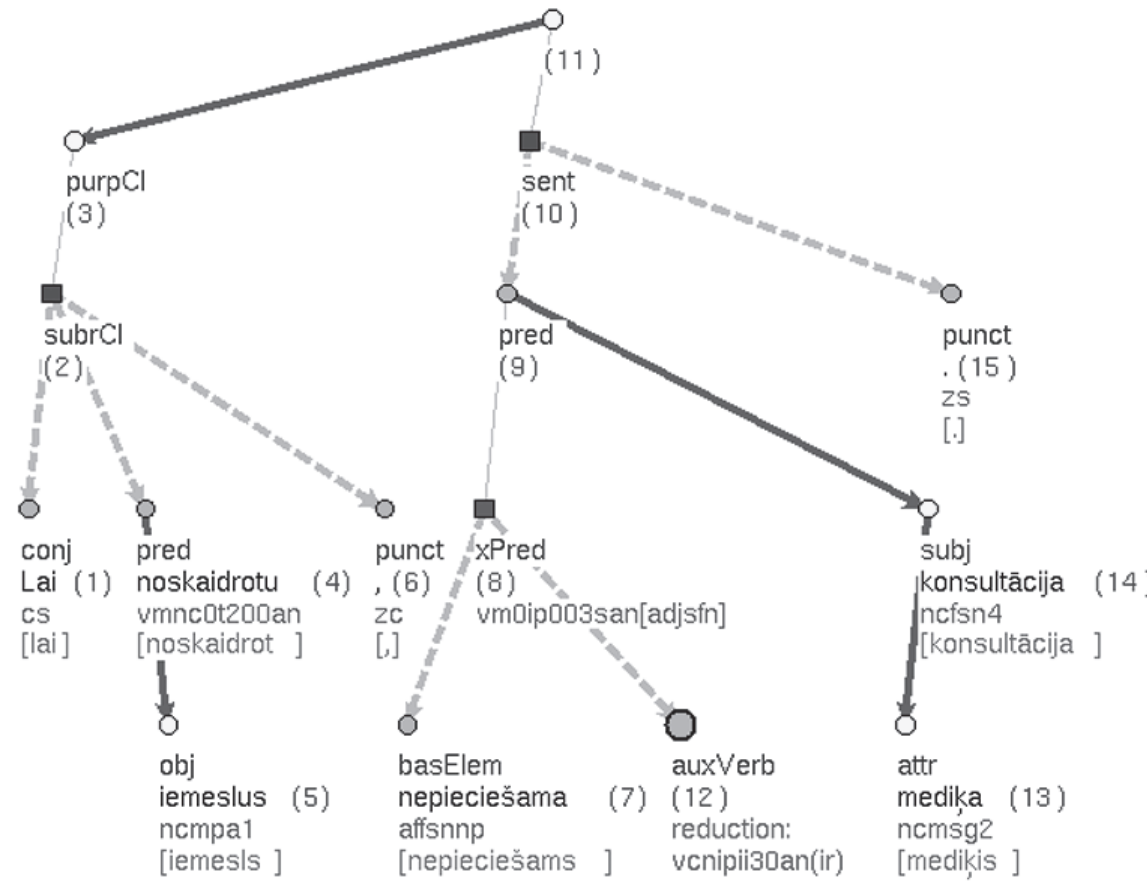

2. attēls. Teikuma Lai noskaidrotu iemeslus, [ir] nepieciešama mediķa konsultācija sintakses koks ar saitingas ir redukciju

\subsection{Sintaktiskās lomas gramatikas modelī}

Hibrīdajā gramatikas modelī sintaktiskās lomas (šajā rakstā šis termins lietots ar nozīmi 'apzīmējums') tiek izmantotas, lai apzīmētu katra teikuma elementa sintaktisko funkciju. Dažas no sintaktiskām lomām var būt attēlotas gan ar vienu vārdu, gan ar frāzi, bet citas sintaktiskās lomas var būt attēlotas tikai ar frāzi, kā, piem., palīgteikumi. Sintaktisko lomu saraksts redzams 1. tabulā.

Ar sintaktiskajām lomām tiek apzīmētas sintaktiskās funkcijas mūsdienu latviešu sintakses teorijā - izteicējs, teikuma priekšmets, papildinātājs, apzīmētājs un apstāklis, kā arī ārpusshēmas komponenti - situants, determinants un sekundāri predikatīvs komponents. Determinatīvi ārpusshēmas komponenti (determinants un situants) parasti ir saistīti ar visu predikatīvo vienību, nevis ar frāzi vai vienu vārdu. Determinants ir teikuma paplašinātājs datīvā, kas nosauc situācijas izjutēju vai īpašnieku un tiek attēlots kā visam teikumam pakārtots teikuma loceklis (Lokmane 2013, 758-759), piem.:

(4) Jums patīk kārtība ne tikai apkārt, bet arī domās.

Situants ir apstāklis, kas nosauc teikumā aprakstītās situācijas apstākḷus un iesaistās teikumā neatkarīgi no vārda sakariem (Lokmane 2013, 760-761), piem.:

(5) Tagad galvenais ir nomierināties pašiem, jo jūsu miers ir jūsu bērna veselības kīla. 


\begin{tabular}{|l|l|}
\hline \multicolumn{2}{|c|}{ Atkarību sintaktiskās lomas } \\
\hline Pred & izteicējs \\
\hline Subj & teikuma priekšmets \\
\hline Attr & apzīmētājs \\
\hline Obj & papildinātājs \\
\hline Adv & apstāklis \\
\hline Spc & $\begin{array}{l}\text { sekundāri predikatīvs } \\
\text { komponents }\end{array}$ \\
\hline Sit & situants \\
\hline Det & determinants \\
\hline No & partikula \\
\hline
\end{tabular}

\begin{tabular}{|l|l|}
\hline \multicolumn{2}{|c|}{ Konstrukciju sintaktiskās lomas } \\
\hline subjCl & $\begin{array}{l}\text { teikuma priekšmeta } \\
\text { palīgteikums }\end{array}$ \\
\hline predCl & izteicēja palīgteikums \\
\hline attrCl & apzīmētāja palīgteikums \\
\hline objCl & papildinātāja palīgteikums \\
\hline appCl & pielikuma palīgteikums \\
\hline placeCl & vietas apstākḷa palīgteikums \\
\hline timeCl & laika apstākḷa palīgteikums \\
\hline manCl & veida apstākḷa palīgteikums \\
\hline degCl & mēra apstākḷa palīgteikums \\
\hline causCl & cēloṇa apstākḷa palīgteikums \\
\hline purpCl & nolūka apstākḷa palīgteikums \\
\hline condCl & $\begin{array}{l}\text { nosacījuma apstākḷa } \\
\text { palīgteikums }\end{array}$ \\
\hline cnsecCl & seku palīgteikums \\
\hline compCl & salīdzinājuma palīgteikums \\
\hline cncesCl & pieḷāvuma palīgteikums \\
\hline motivCl & pamatojuma palīgteikums \\
\hline quasiCl & relatīvais palīgteikums \\
\hline ins & iespraudums, iestarpinājums \\
\hline dirSp & tiešāa runa \\
\hline
\end{tabular}

1. tabula. Sintaktiskās lomas

LVTB situants attēlots kā no visa teikuma atkarīgs teikuma loceklis. Tomēr minētās situanta nošķiršanas pazīmes pamatā ir semantiskas (verba valences nosacītas) un nav tik formāli aprakstāmas, lai varētu izveidot konsekventu marķējumu LVTB, tāpēc šobrīd šāda loma pamatā tiek izmantota gadījumos, kad situatīvs apstāklis attiecināts uz divām neatkarīgām teikuma daḷām, piem.:

(6) ک̌oreiz, salīdzinājumāa ar citiem mačiem, komandai ir īsāks kandidātu saraksts un sastāvā ieklauti vien 18 futbolisti.

Savukārt sekundāri predikatīva komponenta izpratne ir l̦oti plaša (Lokmane 2013, 742-757; Nītiņa 2013, 810-819), un tā sastāvs var būt ḷoti atšķirīgs - dažādas nominālas frāzes sekundāro predikātu nosaukšanai (7), salīdzinājuma konstrukciju salīdzinātājdaḷa (8), divdabji (9):

(7) Tètis sēdēja gultā skumǰs, lai gan nekur nebija gājis, un darbojās ap celgaliem ...

(8) Šie Ziemeļāfrikāņu zēni ir pat sliktākā situācijā nekā meitenes. 


\section{(9) Beigās Antigone izdara pašnāvību pakaroties.}

Sintaktiskās lomas tiek lietotas, lai nosauktu teikumā iesaistītos palīgteikumus un citas sintaktiskās konstrukcijas, piem., iespraudumus, tiešo runu. Šajos gadījumos sintaktiskā loma tiek piešķirta virsotnei, kura ir izvērsta noteiktā pieturzīmju konstrukcijas frāzē (sk. raksta 3.2.3. nodaḷu).

Arī partikulām LVTB ir sintaktiskā loma (no). Ja partikula attiecas tikai uz vienu teikuma locekli, tā ir pakārtota konkrētai vārdformai (10) - partikula tikai iegūst sintaktisko lomu no un tiek pakārtota teikuma loceklim Jānis. Ja partikula nav saistīta ar kādu noteiktu teikuma locekli (11), tā tiek attēlota kā pieturzīmju konstrukcijas (teikuma vai teikuma daḷas) sastāvdaļa.

(10) Atnāca tikai Jānis.

(11) Laikam nav vērts jautāt sīkāk.

Problēmas sintaktisko funkciju marķēšanā rada tas, ka līdz ar sekundāri predikatīva komponenta izpratnes paplašināšanu strukturālās sintakses ietvaros šajā grupā tiek iekḷauts arvien plašāks parādību loks (Lokmane 2013, 742-757), tāpēc mainījusies arī tradicionālajā sintaksē (Ahero et al. 1962, 247-373) minēto atkarīgo teikuma locekḷu (apzīmētāja, papildinātāja un apstākḷla) izpratne, tiem atbilstošo parādību loks ir sašaurinājies un jāpārskata. Ilze Lokmane (2013, 761-765) vārda sakaru nosacītus paplašinātājus šķir pēc nozīmes, un tas rada atškirīības no teikuma locekḷu izpratnes tradicionālajā gramatikā, tomēr trūkst plašāka teorētiska apraksta, kas apvienotu tradicionālās sintakses mantojumu ar mūsdienu sintakses izpratni. Piem., tradicionālajā gramatikā lietvārda ǵenitīvs ar subjekta nozīmi pie lietvārda, kas darināts no verba, tiek uzskatīts par apzīmētāju (suna riešana), bet jaunākās akadēmiskās gramatikas interpretācijā šādam subjekta ǵenitīvam sintaktiskā funkcija nav norādīta, tikai teikts, ka tas ir paplašinātājs ar subjekta nozīmi.

Sekundāri predikatīvu komponentu aprakstā šādi paplašinātāji ar subjekta nozīmi nav iekḷauti, tāpēc nav skaidrs, kādu sintaktisko lomu tiem pieškirt LVTB. Tāpat I. Lokmane $(2013,763)$ min iespēju paplašināt atribūtu izpratni un dalu tradicionālo apstākḷu interpretēt kā atribūtus, tātad apzīmētājus (loti priecīgs, jautri smieties), tomēr paplašinātāju ar adverbiālu nozīmi jeb apstākḷu aprakstā šì pieeja nav īstenota. LVTB pakārtotie teikuma locekḷii - apzīmētājs, papildinātājs un apstāklis - marḳēti pēc tradicionālās sintakses izpratnes, neiekḷaujot šajās lomās parādības, kas iederas sekundāri predikatīvu komponentu grupā.

Ir sintaktiskās lomas, kas tiek piešķirtas tikai noteiktām frāžu sastāvdaḷām:

- X-vārdos, ko veido no viena patstāvīga vārda un viena vai vairākiem palīgvārdiem, patstāvīgais vārds iegūst lomu basElem, bet palīgvārdam

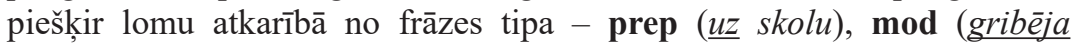

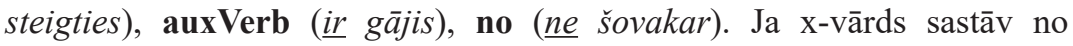
vairākiem patstāvīgiem vārdiem, piem., pielikuma konstrukcija xApp (māsa Anna), tad visi frāzes elementi iegūst lomu basElem.

- Pieturzīmju konstrukcijas sastāv no viena basElem vai pred, vienas vai vairākām pieturzīmēm ar lomu punct, dažos gadījumos pieturzīmju konstrukcijas sastāvdaḷa var būt saiklis conj vai arī partikula ar lomu no, piem., 3. attēlā redzamajā teikumā ir teikuma priekšmeta palīgteikums 
subjCl, kuru veido pieturzīmju konstrukcija subrCl - tā sastāv no pieturzīmes punct, saikḷa conj un predikāta pred, kuram pakārtots viss palīgteikuma koks.

- Sakārtojuma sastāvdaḷas ir vienlīdzīgie teikuma locekḷi vai teikuma daḷas ar lomu crdPart, pieturzīmes ar lomu punct un/vai saikḷi ar lomu conj.

\subsection{Frāzes gramatikas modelī}

Hibrīdajā gramatikas modelī tiek šķirtas triju veidu frāzes:

- X-vārda frāze sastāv no vairākiem vārdiem, bet visa frāze veic vienu sintaktisko funkciju. Ar x-vārdiem attēlo saliktus teikuma locekḷus, piem., saliktu izteicēju, prievārdisku konstrukciju, nosaukumu u.c. vairākvārdu vienības.

- Pieturzīmju konstrukcija attēlo konstrukcijas, kas saistītas ar pieturzīmju lietojumu teikumā, piem., palīgteikumu, divdabja teicienu, izsauksmes vārdu, iespraudumu. PMC sastāv no vienas vai vairākām pieturzīmēm un tā bāzes elementa, kura dēḷ tiek lietota pieturzīme.

- Sakārtojuma konstrukcijas attēlo sakārtojuma sakaru un sastāv no vienlīdzịgiem teikuma locekḷiem vai vienlīdzīgām teikuma dạ̦ām, saikḷiem un pieturzīmēm, kas atdala vienlīdzīgus teikuma locekḷus vai vienlīdzīgas teikuma daḷas.

X-vārdiem un sakārtojuma konstrukcijām tiek norādītas morfosintaktiskās paz̄imes, kas raksturo, kā frāze iesaistās teikumā.

Katram frāžu veidam ir vairāki tipi, savukārt daḷai x-vārdu ir arī apakštipi, kurus norāda frāzes morfolog̣isko pazīmju aprakstā. Tas ḷauj škirt dažādas sintakses teorijā aprakstītās parādības.

\subsubsection{X-vārdi}

X-vārdi gramatikas modelī tiek izmantoti, lai attēlotu vairākvārdu frāzes, kas funkcionē kā viens vesels sintaktisks elements. Dažas frāzes sintakses teorijā ir precīzi un plaši aprakstītas - salikti izteicēji xPred (saliktas laika formas, sastata izteicēji, izteicēji ar semantisku modificētāju), prievārdiskas konstrukcijas xPrep (gan tradicionālas, gan konstrukcijas ar prievārdisku adverbu), skaitḷa vārdu savienojumi xNum. Tomēr daḷa x-vārdu gramatikās aprakstīti nepilnīgi, tādēḷ, veidojot gramatikas modeli, to apraksts un dalījums apakštipos veidots, balstoties uz valodas materiālu (pilnu x-vārdu sarakstu sk. 2. tabulā).

- Salīdzinātājdaļa xSimile salīdzinājuma konstrukcijās gramatikās aprakstīta pamatā tikai pielīdzinājumos ar saikli $k \bar{a}$, bet nav skatīts tās lietojums salīdzinājumos ar saikli nekā. Valodas materiāls rāda, ka var izveidot divus salīdzinātājdaḷas apakštipus atkarībā no tā, vai frāze lietota konstrukcijā ar pielīdzinājuma nozīmi un struktūru (12) vai ar salīdzinājuma nozīmi un struktūru (13).

(12) Bet tu jau esi tik vājš $\boldsymbol{k} \overline{\boldsymbol{a}}$ niedre.

(13) Tas bija ḷoti parasts stāsts, kurā es klausījos tikai ar vienu ausi un man likās, ka es to varētu izstāstìt labāk nekā viṇa. 
Turklāt frāzes tagā tiek īpaši marķētas gramatizējušās salīdzinājuma konstrukcijas vairāk $k \bar{a} / n e k \bar{a}$, mazāk $k \bar{a} / n e k \bar{a}$ u.c., lai gan latviešu valodas sintakses teorijā pagaidām šādas konstrukcijas nav šķirtas.

- Vārdkopas analoga (Skujiņa 2007, 435) subrAnal izpratne sintakses teorijā nav precizēta, Intas Freimanes darbā „,Valodas kultūra teorētiskā skatījumā" (Freimane 1993, 244-245) termins lietots attiecībā uz šauru valodas parādību loku (mēs visi, tāds smieklīgs, kaut kas labs), tomēr tur minētās pazīmes l̦auj š̀̃ termina izpratni paplašināt un attiecināt to arī uz citiem vairākvārdu elementiem, ko mēdz saukt par sintaktiski vai jēdzieniski nedalāmiem vārdu savienojumiem (Ceplītis et al. 1989, 44-45), piem.:

(14) viens no klausītājiem

(15) labākais no aktieriem

- Ar namedEnt aprakstīti vairākvārdu nosaukumi, piem., cilvēka vārds Jānis Bērziņš. Kā frāze tiek attēloti tikai tie nosaukumi, kuru iekšējā struktūrā nav pakārtojuma sakara, piem., Bērziņš Investment. Ja nosaukumā ir pakārtojuma sakars, frāze netiek veidota, piem., Latvijas Universitāte netiek attēlots kā x-vārds.

\begin{tabular}{|c|c|c|c|}
\hline X-vārds & Apraksts & Apakštips & Apraksts \\
\hline \multirow[t]{3}{*}{ xPrep } & \multirow[t]{3}{*}{$\begin{array}{l}\text { prievārdiska } \\
\text { konstrukcija }\end{array}$} & [pre] & $\begin{array}{l}\text { konstrukcija ar prepozitīvu } \\
\text { prievārdu: ar roku }\end{array}$ \\
\hline & & [post] & $\begin{array}{l}\text { konstrukcija ar postpozitīvu } \\
\text { prievārdu: naudas dẹl }\end{array}$ \\
\hline & & [rel] & $\begin{array}{l}\text { konstrukcija ar prievārdisku } \\
\text { adverbu: tuvu ābelei }\end{array}$ \\
\hline \multirow[t]{3}{*}{ xPred } & \multirow[t]{3}{*}{ salikts izteicējs } & [act], [pass] & saliktie laiki: ir gājis \\
\hline & & $\begin{array}{l}\text { [subst], [adj], } \\
\text { [pronom], [inf], } \\
\text { [num], [adv] }\end{array}$ & $\begin{array}{l}\text { sastata izteicēji - nomināli, } \\
\text { pronomināli, adverbiāli un } \\
\text { sastata izteicējs ar infinitīvu: } \\
\text { bija spēcīgs }\end{array}$ \\
\hline & & $\begin{array}{l}\text { [modal], [phase], } \\
{[\text { expr] }}\end{array}$ & $\begin{array}{l}\text { salikts izteicējs ar modificētāju: } \\
\text { gribēja skriet }\end{array}$ \\
\hline xNum & \multicolumn{3}{|c|}{ skaitl̦a vārdu savienojums: divdesmit četri } \\
\hline \multirow[t]{2}{*}{ xApp } & \multirow[t]{2}{*}{ pielikums } & [agr] & $\begin{array}{l}\text { saskaņots pielikums: } m \bar{a} s a \\
\text { Anna }\end{array}$ \\
\hline & & [non] & $\begin{array}{l}\text { nesaskan,ots pielikums: } \\
\text { laikraksts „Diena” }\end{array}$ \\
\hline \multirow[t]{2}{*}{ xSimile } & \multirow[t]{2}{*}{ salīdzinātājdaḷa } & [sim] & pielīdzinājums: $k \bar{a}$ Jānis \\
\hline & & [comp] & salīdzinājums: nekā vakar \\
\hline \multirow[t]{2}{*}{ xParticle } & \multirow{2}{*}{$\begin{array}{l}\text { konstrukcijas ar } \\
\text { partikulu (partikula } \\
\text { attiecas uz noteiktu } \\
\text { teikuma locekli un } \\
\text { ir fiksētā pozīcijā) }\end{array}$} & [aff] & $\begin{array}{l}\text { konstrukcija bez nolieguma: ik } \\
\text { rìtu, kaut viens }\end{array}$ \\
\hline & & {$[\mathrm{neg}]$} & $\begin{array}{l}\text { konstrukcija ar noliegumu: } n e \\
\text { vienmēr }\end{array}$ \\
\hline
\end{tabular}




\begin{tabular}{|c|c|c|c|}
\hline X-vārds & Apraksts & Apakštips & Apraksts \\
\hline namedEnt & \multicolumn{3}{|c|}{ personvārdi, organizāciju nosaukumi: Jānis Bērziņš } \\
\hline \multirow[t]{6}{*}{ subrAnal } & \multirow[t]{6}{*}{ vārdkopas analogs } & {$[\mathrm{vv}]$} & $\begin{array}{l}\text { vietniekvārdu savienojums: } \\
\text { mēs visi, tas pats }\end{array}$ \\
\hline & & [ipv] & $\begin{array}{l}\text { vietniekvārda un adjektīva } \\
\text { vai adjektîviska divdabja } \\
\text { savienojums: tāds interesants }\end{array}$ \\
\hline & & {$[\mathrm{skv}]$} & $\begin{array}{l}\text { vietniekvārda un skaița vārda } \\
\text { savienojums: abi divi, visi trīs }\end{array}$ \\
\hline & & [set] & $\begin{array}{l}\text { kopuma konstrukcija: viens no } \\
\text { viniem, labākais no aktieriem }\end{array}$ \\
\hline & & [sal] & $\begin{array}{l}\text { gramatizējušās salīdzinājuma } \\
\text { konstrukcijas: } t \bar{a} d s k \bar{a} \\
\text { noraizējies, tāds } k \bar{a} \text { rēgs }\end{array}$ \\
\hline & & [part] & $\begin{array}{l}\text { vairākvārdu partikula: it kā, } \\
\text { diez vai }\end{array}$ \\
\hline coordAnal & \multicolumn{3}{|c|}{ vārdrindas analogs: trīs četri } \\
\hline unstruct & \multicolumn{3}{|c|}{$\begin{array}{l}\text { teksta primitīvu virknes bez gramatiskās struktūras: } \\
\text { per aspera ad astra, } f(x)=\sin x+|x|+17\end{array}$} \\
\hline phraseElem & \multicolumn{3}{|c|}{$\begin{array}{l}\text { frazeoloğiska vienība, kas iekḷaujas teikumā kā viens veselums: } \\
\text { [pabeidza] viens un divi, ka tavu almu māteri }\end{array}$} \\
\hline
\end{tabular}

2. tabula. X-vārdu tipi un apakštipi

- Pielikuma konstrukcija xApp, kurā iekḷauti gan saskaņoti (16, 17), gan nesaskaņoti (18) pielikumi. Par šīs konstrukcijas iekšējiem sintaktiskajiem sakariem pastāv dažādi uzskati (Lokmane 2013, 766), bet frāze likās atbilstošākais veids, kā to marḳēt LVTB.

(16) māte daba

(17) māsa Anna

(18) laikraksts „Diena”

Pamatā ar x-vārdiem tiek attēloti sintakses teorijā aprakstītie saliktie teikuma locekḷi, bet x-vārdi ḷauj modelī iekḷaut arī tādas sintaktiskās parādības, kas vēl nav sīkāk aprakstìtas, tomēer, pēc LVTB veidotāju domām, veido noteiktu vairākvārdu elementu tipu. Arī tad, ja kāda x-vārda interpretācija raisa diskusiju, šāds marķējums ḷauj atrast līdzīgos gadījumus un veikt pētījumu, lai precizētu attiecīgās parādības izpratni.

Modelis l̦auj izmantot x-vārdu pieeju arī tādām parādībām, kas tradicionāli netiek uzskatītas par saliktiem teikuma locekḷiem, bet kas gramatikas aprakstos tiek sauktas par vairākvārdu elementiem - vairākvārdu partikulām un saikḷiem. Šis varētu būt viens no nākamajiem soḷiem modeḷa attīstǐšanā - vairākvārdu partikulas šobrīd tiek marķētas kā viens no vārdkopas analoga subrAnal apakštipiem, tomēr tās neatbilst vārdkopas analoga izpratnei. Vairākvārdu elementiem ar palīgvārda funkciju būtu jāizveido savs x-vārda tips ar diviem apakštipiem - vairākvārdu 
partikulām un vairākvārdu saikḷiem. Vēl jāpēta un jāprecizē arī tādu vārdu savienojumu kā (19) iederība vārdkopas analoga kategorijā.

(19) tāds kā noraizējies

\subsubsection{Sakārtojuma konstrukcijas}

Sakārtojuma konstrukcijas tiek izmantotas, lai attēlotu sakārtojuma sakaru vienlīdzīgus teikuma locekḷus (crdParts) vai vienlīdzīgas teikuma daḷas (crdClauses). Frāze ietver vienlīdzīgos teikuma locekḷus, kā arī saikḷus un pieturzīmes, kas tos atdala. Var attēlot arī divpakāpju sakārtojumu - gadījumus, kad kāds no vienlīdzīgiem teikuma locekḷiem ir izvērsts plašāk divos vai vairākos vienlīdzīgos teikuma locekḷos, piem., teikuma daḷā .. vīri kāpa stabos un savienoja vai remontēja vadus izteicēji savienoja un remontēja abi kopā ir vienlīdzīgi ar izteicēju kāpa (sk. 3. attēlu).

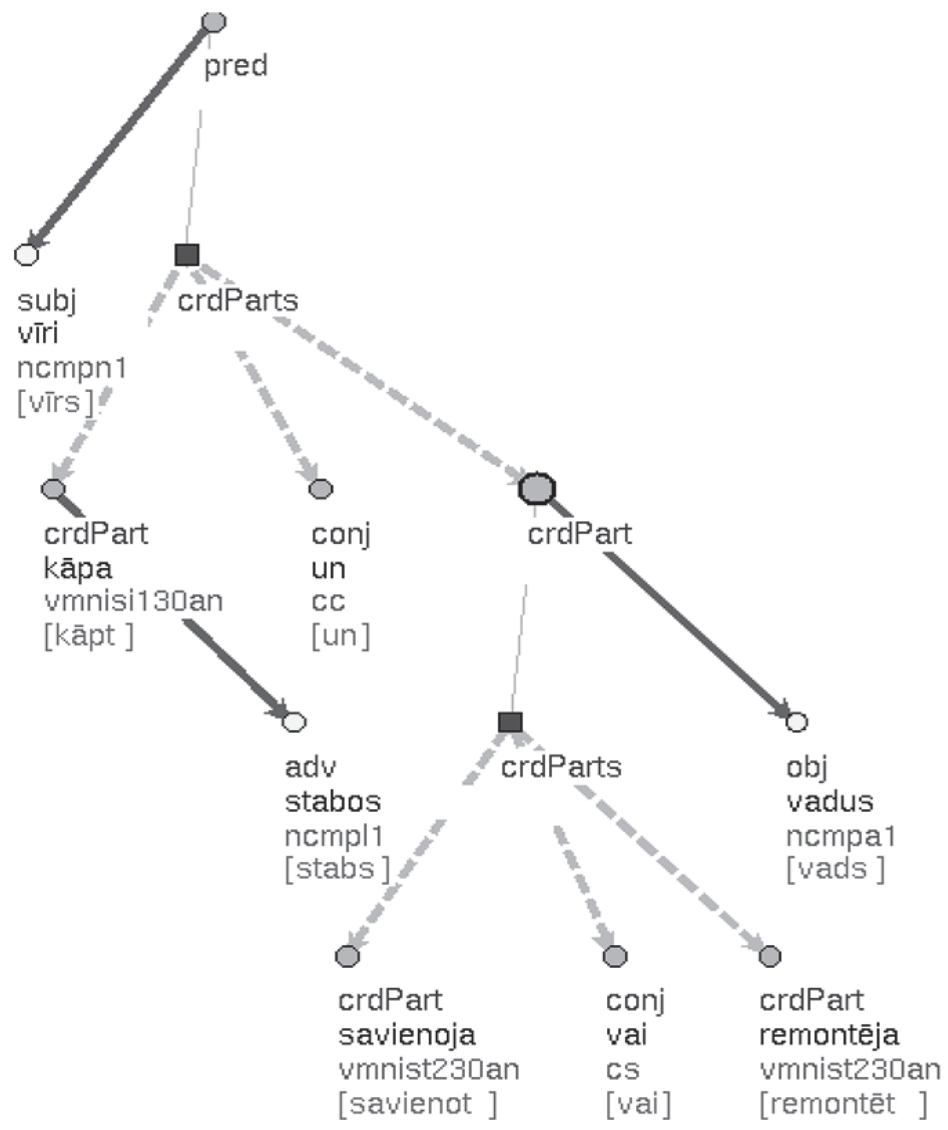

3. attēls. Divpakāpju sakārtojuma konstrukcija. Sintakses koks teikuma daļai .. vīri kāpa stabos un savienoja vai remontēja vadus 


\subsubsection{Pieturzimju konstrukcijas}

Pieturzīmju konstrukcijas gramatikas modelī ir frāzes, kas ļauj piesaistīt pieturzīmes tam teikuma elementam vai teikuma daḷai, kuras dēl teikumā lietotas pieturzīmes. Līdz ar to arī teikuma beigu pieturzīme ar visu teikumu kopā veido pieturzīmju konstrukciju sent, divdabja teiciens kopā ar to atdalošajām pieturzīmēm veido spcPmc, tiešā runa kopā ar kolu un pēdiņām vai domuzīmēm veido dirSpPmc utt. 4. attēlā redzamas trīs pieturzīmju konstrukcijas - teikums (sent), palīgteikums (subrCl) un iespraudums (insPmc).

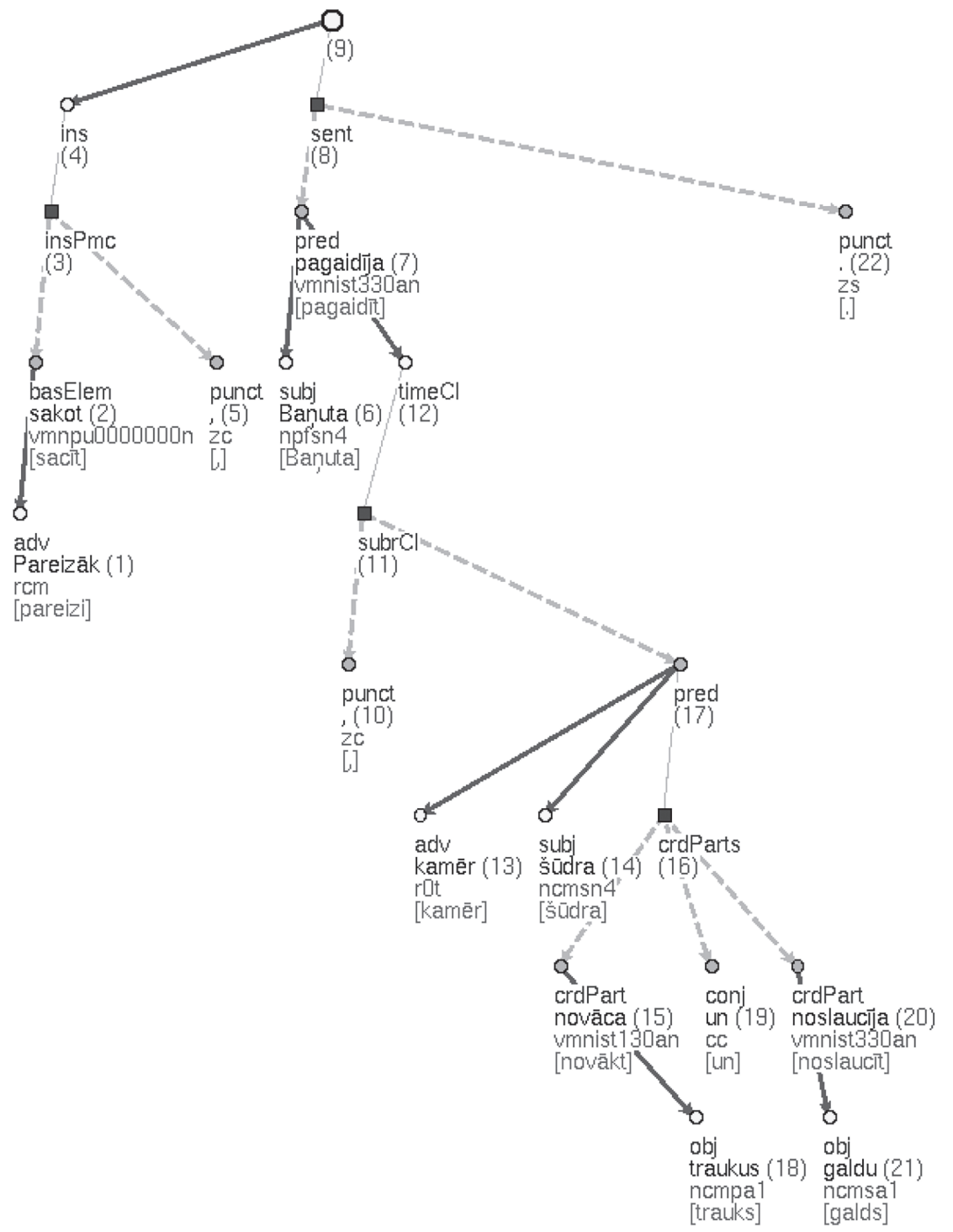

4. attēls. Pieturzīmju konstrukcijas teikumā. Teikuma Pareizāk sakot, Baņuta pagaidīja, kamēr šūdra novāca traukus un noslaucīja galdu sintakses koks 
Šāds iedalījums pamatā atbilst sintakses teorijā (Lokmane 2013) aprakstītajām konstrukcijām, tomēr arī šeit modelis būtu vēl jāattīsta, lai panāktu konsekventu sekundāri predikatīvu konstrukciju marķēšanu, vienlaikus nepazaudējot teorijā aprakstītos konstrukciju tipus - daḷa no konstrukcijām, kas ir sekundāri predikatīvas, nav šķirtas kā atsevišķi tipi, piem., savrupinājumi un paskaidrojošās vārdu grupas tiek veidotas zem atkarību lomas spc ar PMC frāzi spcPmc, tāpat kā divdabja teicieni, līdz ar to tās atrast korpusā nav tik vienkārši. Savukārt iespraudumu konstrukcija insPmc aptver gan nepredikatīvas, gan sekundāri predikatīvas, gan predikatīvas vienības, no kurām atšksirīgi marķēti tikai predikatīvi iespraudumi, norādot, ka to sastāvā ir predikatīva vienība pred, nevis patstāvīgs vārds basElem, kā pirmajos divos gadījumos. Pieturzīmju konstrukciju saraksts redzams 3. tabulā.

\begin{tabular}{|l|l|}
\hline \multicolumn{1}{|c|}{ PMC } & \multicolumn{1}{c|}{ Apraksts } \\
\hline sent & teikums (koka sakne) \\
\hline utter & izteikums (koka sakne) \\
\hline mainCl & virsteikums, neatkarīga teikuma daḷa \\
\hline subrCl & palīgteikums \\
\hline interj & izsauksmes vārds pieturzīmēs \\
\hline spcPmc & divdabja teicieni, savrupinājumi, paskaidrojošas vārdu grupas \\
\hline insPmc & iespraudumi un iestarpinājumi pieturzīmēs \\
\hline particle & partikula pieturzīmēs \\
\hline dirSpPmc & tiešās runas pieturz̄̄mju konstrukcija \\
\hline address & uzruna \\
\hline quot & pēdin̄u lietojums, kas nav saistīts ar tiešo runu - citāts, nosaukums \\
\hline
\end{tabular}

3. tabula. Pieturzīmju konstrukciju tipi

\section{Secinājumi}

„Latviešu valodas sintaktiski marķētā korpusa” izveidē izmantotais hibrīdais gramatikas modelis palīdz attēlot latviešu sintakses teorijā aprakstītās vārdkopas, analītiskās leksēmas un saliktos teikuma locekḷus. Izveidotie frāžu tipi un apakštipi aptver lielu daḷu sintakses teorijā aprakstīto parādību. Atšķirībā no atkarību gramatikas modeḷiem tas l̦auj piešķirt vienu sintaktisko funkciju vairākvārdu frāzei, kā arī l̦auj šķirt visas frāzes atkarīgos no šīs frāzes atsevišķa elementa atkarīgajiem. Sīki izstrādātais frāžu sastāvdaḷu marḳējums ḷauj transformēt datus uz dažādiem atkarību modeḷiem, nemainot oriǵinālā model̦a marḳēšanas principus un datus.

LVTB ir l,oti vērtīgs pētījumu avots, korpusa apjoms ir pietiekams, lai to varētu izmantot dažādiem latviešu valodas sintakses pētījumiem. Īpaši noderīgi būtu pētījumi par nepiln̄̄gi aprakstītām, bet plaši sastopamām sintaktiskajām konstrukcijām latviešu valodā, piem., vārdkopas analogiem, pielikuma konstrukcijām, reducētiem semantiskiem modificētājiem saliktos izteicējos. Korpusa izmantošana sintakses pētījumos ḷautu gan novērtēt, gan uzlabot LVTB gramatikas modeli. 
Turpmāk paredzēts palielināt LVTB apjomu, samazināt manuāli piel̦autu kḷūdu un nekonsekventa marķējuma gadījumu skaitu, kā arī attīstīt gramatikas modeli, izveidojot sekundāri predikatīvu komponentu apakštipus, ieviešot jaunu X-vārdu vairākvārdu saikḷiem u. tml., lai pēc iespējas precīzāk aptvertu latviešu valodas gramatikā aprakstītās parādības.

\section{Saīsinājumi}

$\begin{array}{ll}\text { LVK2018 } & \text { Lìdzsvarotais latviešu valodas tekstu korpuss } \\ \text { LVTB } & \text { Latviešu valodas sintaktiski mark̄ètais korpuss } \\ \text { PMC } & \text { pieturzìmju konstrukcija (Punctuation Mark Construction) } \\ \text { PML } & \text { datu formāts Prague Markup Language }\end{array}$

\section{Avots}

Latviešu valodas sintaktiski mark̦ētais korpuss. Pieejams: https://sintakse.korpuss.lv.

\section{Literatūra}

1. Ahero, Antonija et al. 1962. Mūsdienu latviešu literārās valodas gramatika. II. Sintakse. Rīga: Latvijas PSR Zinātṇu akadēmijas izdevniecība.

2. Bārzdiņš, Guntis, Gruzītis, Normunds, Nešpore, Gunta, Saulīte, Baiba. 2007. Dependency-Based Hybrid Model of Syntactic Analysis for the Languages with a Rather Free Word Order. Proceedings of the 16th Nordic Conference of Computational Linguistics (NODALIDA). Nivre, Joakim, Kaalep Heiki-Jaan, Muischnek Kadri, Koit Mare (eds.). Tartu: University of Tartu, 13-20.

3. Ceplītis, Laimdots, Rozenbergs, Jānis, Valdmanis, Jānis. 1989. Latviešu valodas sintakse. Rīga: Zvaigzne.

4. Freimane, Inta. 1993. Valodas kultūra teorētiskā skatījumāa. Rīga: Zvaigzne.

5. Grūzītis, Normunds, Pretkalniņa, Lauma, Saulīte, Baiba, Rituma, Laura, NešporeBērzkalne, Gunta, Znotiņš, Artūrs, Paikens, Pēteris. 2018. Creation of a Balanced State-of-the-Art Multilayer Corpus for NLU. Proceedings of the 11 th International Conference on Language Resources and Evaluation (LREC). Calzolari, Nicoletta et al. (eds.). Miyazaki: European Language Recources Association (ELRA), 45064513.

6. Hajič, Jan, Hladká, Barbora, Pajas, Petr. 2001. The Prague Dependency Treebank: Annotation Structure and Support. Proceedings of the IRCS Workshop on Linguistic Databases. Bird, Steven, Liberman, Mark, Buneman, Peter (eds.). Philadelphia: University of Pensylvania, 105-114.

7. Levāne-Petrova, Kristīne. 2019. LVK2018: Līdzsvarotais latviešu valodas tekstu korpuss, tā nozīme gramatikas pētījumos. Valoda: nozīme un forma. 10. Latvijas gramatiskā doma gadsimta gaitā. Kalnača, Andra, Lokmane, Ilze (red.). Rīga: LU Akadēmiskais apgāds.

8. Lokmane, Ilze. 2013. Vienkārša teikuma formālā (strukturālā) organizācija. Latviešu valodas gramatika. Nītiņa, Daina, Grigorjevs, Juris (red.). Rīga: LU Latviešu valodas institūts, 710-766.

9. Nešpore, Gunta, Saulīte, Baiba, Bārzdiņš, Guntis, Grūzītis, Normunds. 2010. Comparison of the SemTi-Kamols and Tesnière's Dependency Grammars. 
Proceedings of the 4th International Conference on Human Language Technologies - the Baltic Perspective. Frontiers in Artificial Intelligence and Applications. 219. Skadina, Inguna, Vasiljevs, Andrejs (eds.). Amsterdam: IOS Press, 233-240.

10. Nītina, Daina. 2013. Vienkārša teikuma vai salikta teikuma komponentu paplašinājumi (paplašinātājas struktūras). Latviešu valodas gramatika. Nītiņa, Daina, Grigorjevs, Juris (red.). Rīga: LU Latviešu valodas institūts, 801-829.

11. Nivre, Joakim, Marneffe, Marie-Catherine de, Ginter, Filip, Goldberg, Yoav, Hajič, Jan, Manning, Christopher D., McDonald, Ryan, Petrov, Slav, Pyysalo, Sampo, Silveira, Natalia, Tsarfaty, Reut, Zeman, Daniel. 2016. Universal Dependencies v1: A Multilingual Treebank Collection. Proceedings of the 10th International Conference on Language Resources and Evaluation (LREC). Calzolari, Nicoletta, et al. (eds.). Paris: European Language Recources Association (ELRA), 1659-1666.

12. Paikens, Pēteris. 2008. Lexicon-based morphological analysis of Latvian language. Proceedings of the 3rd Baltic Conference on Human Language Technologies - the Baltic Perspective. Frontiers in Artificial Intelligence and Applications. Čermák, František, Marcinkevičienė, Rūta, Rimkute, Erika, Zabarskaitė, Jolanta (eds.). Vilnius: Vytautas Magnus University, Institute of the Lithuanian Language, 235-240.

13. Paikens, Pēteris, Rituma, Laura, Pretkalniņa, Lauma. 2013. Morphological analysis with limited resources: Latvian example. Proceedings of the 19th Nordic Conference of Computational Linguistics (NODALIDA). Oephen, Stephan, Hagen, Kristin, Johannesen, Janne Bondi (eds.). Oslo: Linköping University Electronic Press, 267-277.

14. Pretkalniņa, Lauma, Nešpore, Gunta, Levāne-Petrova, Kristīne, Saulīte, Baiba. 2011a. A Prague Markup Language Profile for the SemTi-Kamols Grammar Model. Proceedings of the 18th Nordic Conference of Computational Linguistics (NODALIDA). Pedersen, Bolette Sandford, Nešpore, Gunta, Skadiņa, Inguna (eds.). Riga: Northern European Association for Language Technology (NEALT), 303-306.

15. Pretkalniņa, Lauma, Nešpore, Gunta, Levāne-Petrova, Kristīne, Saulīte, Baiba. 2011b. Towards a Latvian Treebank. Actas del 3 Congreso Internacional de Lingüística de Corpus. Tecnologias de la Información y las Comunicaciones: Presente y Futuro en el Análisis de Corpus. Candel Mora, Miguel Angel, Carrió Pastor, Maria Luisa (eds.). Valnecia: Editorial Universitat Politecnica de Valencia, 119-127.

16. Pretkalnina, Lauma, Rituma, Laura. 2012. Syntactic Issues Identified Developing the Latvian Treebank. Proceedings of the 5th International Conference on Human Language Technologies - the Baltic Perspective. Frontiers in Artificial Intelligence and Applications. 247. Tavast, Arvi, Muischnek, Kadri, Koit, Mare (eds.). Amsterdam: IOS Press, 185-192.

17. Pretkalniņa, Lauma, Rituma, Laura, Saulīte, Baiba. 2016. Universal Dependency Treebank for Latvian: A Pilot. Proceedings of the 7th International Conference on Human Language Technologies - the Baltic Perspective. Frontiers in Artificial Intelligence and Applications. 289. Skadina, Inguna, Rozis, Roberts (eds.). Amsterdam: IOS Press, 136-143.

18. Pretkalniṇa, Lauma, Rituma, Laura, Saulīte, Baiba. 2018 Deriving enhanced Universal Dependencies from a hybrid dependency-constituency treebank. Proceedings of the 21st International Conference "Text, Speech, and Dialogue" 
(TSD). Lecture Notes in Computer Science. 11107. Sojka, Petr, Horák, Aleš, Kopeček, Ivan, Pala, Karel (eds.). Brno: Springer-Verlag, 95-105.

19. Skujiņa, Valentīna (red.). 2007. Valodniecības pamatterminu skaidrojošā vārdnīca. Rīga: LU Latviešu valodas institūts.

20. Ten'er, Ljus'en. 1988. Osnovy strukturnogo sintaksisa. Gak, Vladimir (red.). Moskva: Progress. [Pirmizd.: Tesnière, Lucien. 1959. Éléments de syntaxe structurale. Paris: Klincksieck.]

21. Znotiņš, Artūrs. 2016. Word embeddings for Latvian natural language processing tools. Proceedings of the 7th International Conference on Human Language Technologies - the Baltic Perspective. Frontiers in Artificial Intelligence and Applications. 289. Skadina, Inguna, Rozis, Roberts (eds.). Amsterdam: IOS Press, 167-173.

\section{Summary}

This paper describes the development of Latvian Treebank and its grammar model. This corpus is the first syntactically annotated corpus for Latvian, and currently contains approximately 13000 annotated sentences. A hybrid dependency-constituency model was developed in order to describe Latvian syntactic constructions as accurately as possible, augmenting the commonly used dependency grammars with phrase constructions for certain syntactic elements - analytical word forms and relations other than subordination. The grammar model is based on idea of a syntactic nucleus which is a functional syntactic unit consisting of content-words or syntactically inseparable units that are treated.

There are three kinds of phrase constructions in the Latvian Treebank grammar model: $\mathrm{x}$-words, coordination and punctuation mark constructions. X-words are used for analytical forms, compound predicates, prepositional phrases etc. Coordination constructions are used for coordinated parts of sentences and coordinated clauses. Punctuation mark constructions are used to annotate different types of constructions that require the punctuation in the sentence.

The chosen annotation approach and data transformation systems ensure that the corpus is accessible to end users both in the hybrid dependency-constituency model suitable for research of syntactic phenomena in Latvian linguistic tradition, and in the Universal Dependencies multilingual model that is better suited for certain computational linguistics systems.

This work has received financial support from European Regional Development Fund under the grant agreement No. 1.1.1.1/16/A/219 (Full Stack of Language Resources for Natural Language Understanding and Generation in Latvian) in synergy with the grant agreement No. 1.1.1.2/VIAA/1/16/188 (From Abstract Meaning Representation to Natural Language Sentence and Coherent Text Generation).

Keywords: Latvian syntax; treebank; grammar model; dependency syntax; phrase structure grammar. 